\title{
COVID-19 INFEKCIJOS SUKELTA ŪMINE் GALŪNĖS IŠEMIJA: KLINIKINIS ATVEJIS
}

\author{
Rugilė Bružiené $\dot{\mathbf{3}}^{3}$, Gintautas Virketis ${ }^{1,2}$, Darius Brazys ${ }^{2}$ \\ ${ }^{1}$ Klaipédos universitetas, ${ }^{2}$ Klaipédos universitetine ligonine, \\ ${ }^{3}$ Vilniaus universiteto Medicinos fakultetas
}

\begin{abstract}
Raktažodžiai: arterinè trombozè, COVID-19 liga, kvèpavimo funkcijos nepakankamumas (KFN), komplikacijos, ūminè galūnès išemija.
\end{abstract}

\section{Santrauka \\ COVID-19 infekcijai būdingas platus klinikinès išraiškos spektras. Trombozinès komplikacijos venineje sistemoje - dažniausios sergant COVID-19 liga, tačiau arterineje sistemoje jos kelia didelę galūnių amputacijos riziką ir didina mirštamumą. Straipsnyje pristatomas COVID-19 ligos sukeltas ūminès galūnès išemijos klinikinis atvejis su galūnès amputacija ir letalia baigtimi, aptariami šios būklès išsivystymo, diagnostikos ir gydymo ypatumai. Straipsnyje apžvelgiama kitų autorių patirtis, gydant CO- VID-19 liga sergančius pacientus, aptariami šios infek- cijos paveiktame organizme vykstantys patofiziologiniai mechanizmai, sukeliantys kraujo krešejimo, sisteminio uždegiminio atsako, imuninès sistemos pakitimus ir trombozines komplikacijas. \\ Išvados. Ilgalaikis sisteminio heparino vartojimas gali pagerinti chirurginio gydymo efektyvumą, galūnių iš- saugojimą ir sumažinti mirštamumą. Siekiant sumažinti trombozines komplikacijas stacionare gydomiems ser- gantiesiems vidutine ir sunkia COVID-19 ligos forma, rekomenduojama skirti tromboprofilaktini gydymą mažos molekulinès masės ar nefrakcionuotu heparinu.}

\section{İvadas}

Per daugiau nei metus išplitęs sunkaus ūminio respiracinio sindromo koronavirusas 2 (SARS-CoV-2) sukèlè koronaviruso ligos (COVID-19) pandemiją, dèl kurios sergamumas ir mirtingumas visame pasaulyje didejja. $2021 \mathrm{~m}$. rugpjūčio ménesio duomenimis, šia infekcija sirgo daugiau nei $200 \mathrm{mln}$. žmonių ir ji nusinešè daugiau nei 4 milijonus gyvybiu pasaulyje [1]. COVID-19 infekcijai būdingas platus klinikinès išraiškos spektras, nuo besimptomès ar lengvos ligos formos iki kvėpavimo nepakankamumo, ko- agulopatijos, dauginio organu nepakankamumo ir mirties [2]. Didžiausia rizika, susijusi su naujuoju koronavirusu, yra arterinès ar veninès sistemos trombozinès komplikacijos, kurių dažnis siekia net 35- 45 procentus [3]. Arterinès kraujotakos komplikacijos sudaro 4 proc. visų tromboziniu komplikacijų [4]. Manoma, kad arterijose trombų susidaro rečiau dèl tam tikrų ypatumų: kraujotaka arterijose yra greitesnè, spaudimas didesnis, todèl kraujui sunkiau krešèti [5]. Ūminè galūnių išemija - būklè, išsivysčiusi dèl arterinès kraujotakos sutrikimo - reta, tačiau pavojinga COVID-19 ligos komplikacija, susijusi su dideliu mirštamumu ir ypač didele galūnès amputacijos rizika. Įrodyta, kad koronaviruso liga sergančiu pacientų revaskuliarizacijos sėkmingumas yra žymiai mažesnis, nei neinfekuotų pacientų, tačiau, nepaisant sẻkmingo išemijos gydymo, galūnių amputacija reikalinga iki trečdalio sergančiujų, o mirštamumas yra didesnis nei 45 procentai [6].

Tyrimo tikslas - pristatyti COVID-19 ligos sukeltą pavojingą arterinès trombozès komplikacijos klinikinį atveji bei apžvelgti šios ligos išsivystymo, diagnostikos ir gydymo ypatumus.

\section{Klinikinis atvejis}

77 metų pacientè stacionarizuota ị Klaipėdos universitetinès ligoninès COVID-19 skyrių dèl ryškaus dusulio, karščiavimo iki $38,5^{\circ} \mathrm{C}$, kosulio ir didelio bendro silpnumo. Iš anamnezės sužinota, kad pirmieji simptomai atsirado prieš dvi savaites, COVID-19 infekcija patvirtinta prieš 11 dienų iki patekimo ị ligoninę. Atvykus būklè vidutinio sunkumo, nustatyti kvejpavimo funkcijos nepakankamumo (KFN) požymiai - lūpų cianozè, kvèpavimo dažnis (KD) $-22 \mathrm{k} / \mathrm{min}$., deguonies įsotinimas ( $\mathrm{SpO} 2)-87$ proc. be papildomo deguonies $\left(\mathrm{O}_{2}\right)$, širdies veikla ritmiška, arterinis kraujospūdis (AKS) - 160/80 mmHg, širdies susitraukimų dažnis (ŠSD) - $82 \mathrm{k} / \mathrm{min}$. Paciente daug metų serga pirmine arterine hipertenzija, glaukoma, pastoviai vartoja tab. Perindoprili 5 mg 1 k/d. ryte, akių lašus. Operacijų, alergijos nenurodè. 
Atliktuose kraujo tyrimuose stebėta nežymi anemija ( $\mathrm{Hgb}$ - $120 \mathrm{~g} / \mathrm{l}$ ), trombocitozè (PLT - 474*10e9/1), padidèję uždegiminiai rodikliai: CRB $-159,8 \mathrm{mg} / \mathrm{l}$ (norma $0,00-5,00$ ), $\mathrm{PCT}-0,11 \mu \mathrm{g} / \mathrm{ml}($ norma $<0,05)$. Kiti tyrimai: feritinas

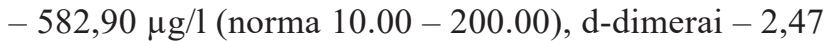
$\mu \mathrm{g} / \mathrm{ml}$ (norma $0,00-0,50$ ), fibrinogenas $-7,32 \mathrm{~g} / 1$ (norma $2,00-4,00)$. Arterinio kraujo dujų tyrimo be papildomo deguonies duomenys, būdingi hipokseminiam kvẻpavimo funkcijos nepakankamumui: $\mathrm{pH}-7,388, \mathrm{pO}_{2}-51,3 \mathrm{mmHg}$, $\mathrm{pCO}_{2}-26,8 \mathrm{mmHg}$. Krūtinès ląstos rentgenogramoje abipus plaučiuose smulkūs ,,matinio stiklo“ plotai, dešinèje ir kairẻje apatinejje dalyje infiltraciniai pakitimai.

Paskyrus gydymą $\mathrm{O}_{2}$ per veido kaukę iki $8 \mathrm{l} / \mathrm{min}$., infuzoterapiją, mažos molekulinès masès heparinus (MMMH) sol. Fraxiparini $0,6 \mathrm{ml} 2 \mathrm{k} / \mathrm{d}$., infuziją su deksametazonu $8 \mathrm{mg} 1$ $\mathrm{k} / \mathrm{d}$., antibiotikoterapiją cefuroksimu $1,5 \mathrm{~g} 3 \mathrm{k} / \mathrm{d}$. 5 gydymo stacionare dieną progresavo KFN požymiai, sustiprejo dusulys ir ramybès metu, padidejo $\mathrm{O}_{2}$ poreikis: $\mathrm{SpO}_{2}$ svyravo - 90 - 92 proc. ribose, padidinus $\mathrm{O}_{2}$ srautą iki $12 \mathrm{l} / \mathrm{min}$. per veido kaukę su rezervuaru. Atlikus krūtinès ląstos kompiuterinę tomografiją (KT), pleuros ertmėje dešinèje nustatytas $0,8 \mathrm{~cm}$ skysčio ruožas. Abipus plaučiuose matinio stiklo zonos ir židiniai, apimantys iki 90 proc. parenchimos ploto. Tarpuplautyje iki 1,0 cm skersmens limfmazgiai. Plautiniame kamiene, abipus pulmonalinèse arterijose bei segmentinèse šakose kontrastinès medžiagos prisipildymo defektų nema-

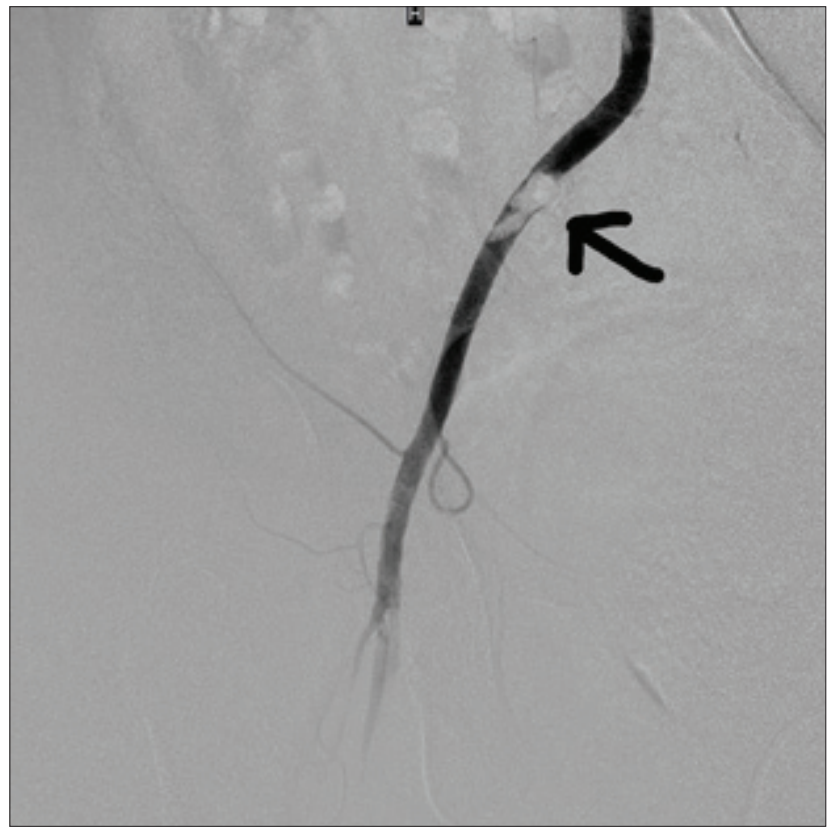

1 pav. Angiograma: A. iliaca communis dextra matomas embolas (pažymėtas rodykle) tyti - už plaučių arterijos trombemboliją (PATE) duomenų nepakanka.

Šeštą gydymo stacionare dieną pacientè staiga pasiskunde dešiniosios kojos, ypač pèdos, skausmu ir jutimo sutrikimu. Apžiūrint dešinioji blauzda ir pèda blyškios, palpuojant nejautri pèda, oda šalta, a. dorsalis pedis ir $a$. poplitea pulsai nečiuopiami, a. femoralis pulsas - silpnas. Atliktas ultragarsinis tyrimas - stebima $a$. femoralis trombozè. Atlikus dešiniosios kojos KT angiografiją, nustatyta: a. iliaca dextra flotuojantis, spindi apie 90 proc. obturuojantis embolas (1 pav.).

Distaliniame $a$. femoralis superficialis (AFS) dextra segmente trombozè, besitęsianti žemyn ị pakinklio (blauzdos) arterijas, kurios fragmentiškai užsipildo iš negausių kolateralių (2 pav.).

KT angiografijos metu nustatyta $a$. profunda femoralis dextra trombozè. Spinalinèje nejautroje atlikta $a$. iliaca dextra trombektomija. Po operacijos būklè pagerèjo: kraujotaka atsikūrè, galūnè šilta, skausmas išnyko. 8 gydymo stacionare dieną pakilo kūno temperatūra ir staiga pasikartojo dešiniosios kojos skausmas. Apžiūrint dešinioji pẻda

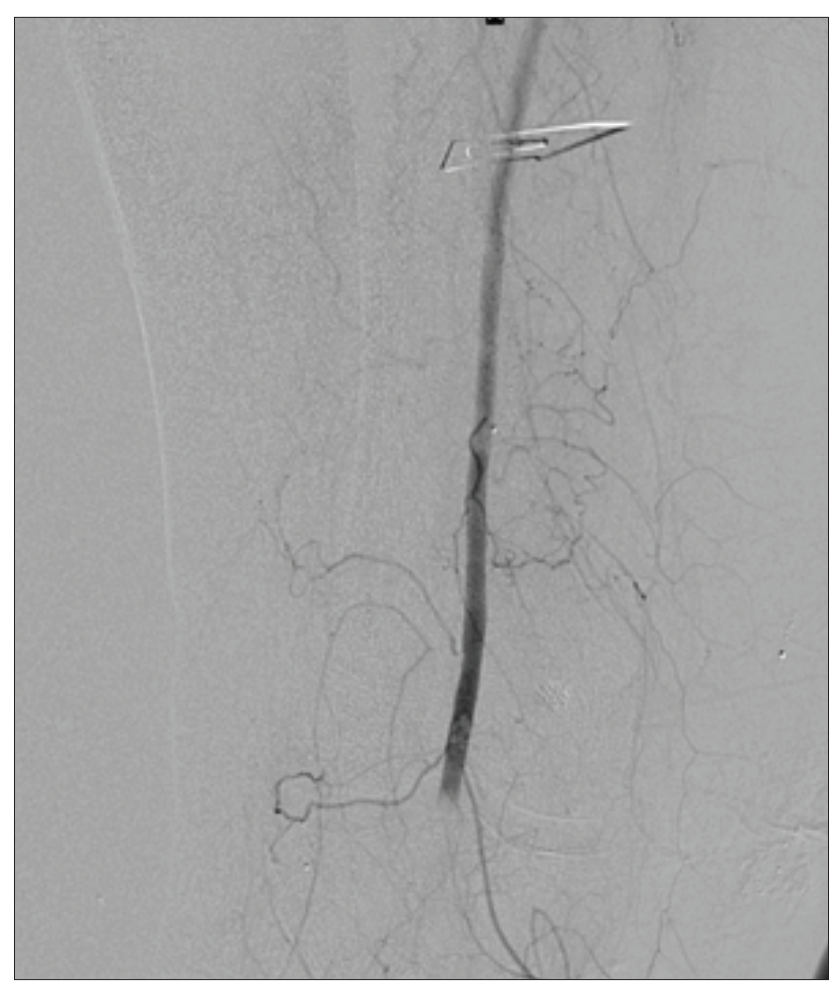

2 pav. Angiograma: a. femoralis superficialis dextra distalinio segmento bei a. poplitea dextra trombozè, kontrastinès medžiagos nutrūkimas ties kelio sąnariu, žemiau matomos smulkios kolateralinès arterijos 
ir apatinis blauzdos trečdalis pabalęs, kiek vèsesnis, pulsas neužčiuopiamas. Atlikta pakartotinè trombektomija, kraujotaka atkurta, tačiau po keleto valandų vèl pasikartojo išemijos požymiai. Pacientei progresavo KFN, skausminis sindromas. Gydymas tęstas Reanimacijos ir intensyviosios terapijos skyriuje (RITS). Atliktas dešiniosios kojos arterijų ultragarsinis tyrimas: stebima kolateralinè kraujotaka, AFS dextra tromboze. Stebima pakartotinė dešiniosios kojos blauzdos arterijos trombozè, sukelta distalinès retrogradinès trombozès. Taikytas operacinis gydymas nedavė efekto. Dèl sunkios pacientès būklès konsiliumo sprendimu rekomenduota atlikti dešiniosios kojos amputaciją šlaunies lygyje. Pacientė operacinio gydymo atsisakè. 9 gydymo dieną atliktų tyrimų rezultatai: leukocitozè (WBC- 13,38*10e9/1), anemija (Hgb-88 g/l), trombocitopenija (PLT-135*10e9/1), padidejję uždegiminiai rodikliai (CRB-163,5 mg/1, PCT-0,17 $\mu \mathrm{g} / \mathrm{ml})$, išliko padidèjusi feritino koncentracija $(493,30 \mu \mathrm{g} / \mathrm{l})$, padidèję d-dimerai (d-dimerai $>4,0 \mu \mathrm{g} / \mathrm{ml}$ ), ryškiai padidèjusios laktathidrogenazès ir kreatinkinazès koncentracijos (LDH-1199 U/1, CK-908 U/1). Kontrolinèje krūtinès ląstos rentgenogramoje stebima neigiama dinamika: infiltracinès (konsolidacinès) sritys abipus plaučiuose didesnès apimties, plaučių oringumas sumažèjęs (3 pav).

Kraujagyslių chirurgo kartotinès apžiūros metu kojos išemija neprogresavo, tačiau teigiamos dinamikos nebuvo, pėdos kraujotaka išliko sutrikusi, mikrocirkuliacija vangi, judesiai per čiurnos sąnarị negalimi. 11 gydymo dieną, pacientei sutikus, buvo atlikta dešiniosios kojos amputacija ties apatiniu šlaunies trečdaliu. Pacientès būklè išliko labai sunki

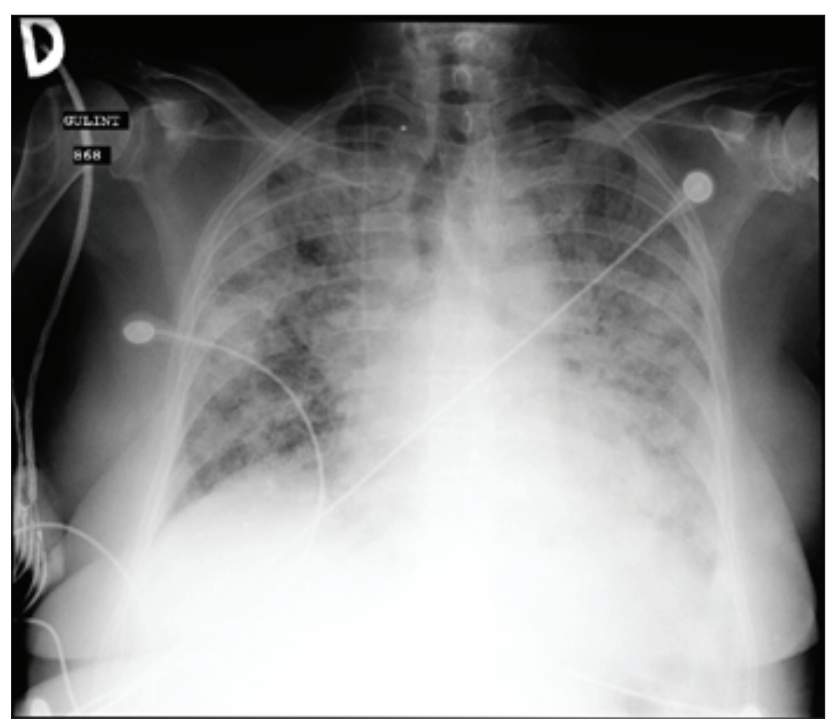

3 pav. Priekinė krūtinès ląstos rentgenograma RITS 11-ą gydymo dieną dèl audinių nekrozès, vis didèjančios bendros organizmo intoksikacijos ir progresuojančio KFN. Praejjus kelioms valandoms po operacijos, vazopresoriu fone, įvyko asistolija, reanimacinès priemonès nebuvo efektyvios, pacientè mirè.

\section{Rezultatu aptarimas}

COVID-19 ligos metu gali būti pažeidžiami visi organai, kurie ekspresuoja angiotenziną konvertuojančio fermento (AKF-2) receptorius. AKF-2 receptoriu yra plaučiuose, širdyje, žarnyno epitelyje, inkstuose bei kraujagyslèse [7,9]. SARS-CoV-2 virusas turi tam tikrų patofiziologinių mechanizmų, labai susijusių su krešèjimo sistemos pakitimais. Sergantieji COVID-19 liga, sutrikus kraujo krešèjimo rodikliams, linkę ị tromboembolinius reiškinius. Koronaviruso ligai būdingos trys fazès: inkubacinis periodas, plaučių ligos ir pernelyg stiprus sisteminis imuninis atsakas. Pirmosios fazès metu virusas replikuojasi, antrosios - vyksta lokalus uždegimas plaučiuose. Paskutinèje, labiausiai pavojingoje ligos stadijoje vystosi pernelyg stiprus imuninis atsakas, išsiskiria daug citokinų ir kitų uždegimų faktorių, o kai kuriais atvejais pažeidžiami ekstrapulmoniniai organai [8].

Sisteminio uždegiminio atsako sindromo vaidmuo, endotelio disfunkcija, krešejimo kaskados aktyvacija, viruso sukeltas antrinis antifosfolipidinis sindromas, imunotrombozè, hipoksija moksliniuose šaltiniuose nurodomi kaip pagrindiniai patofiziologiniai mechanizmai, galintys paaiškinti ryši tarp arterinių tromboembolinių ịvykių ir COVID-19 ligos [9-15].

Panašiai ị sepsio sukeltą endotelio disfunkciją, pasižyminčią pertekline trombino gamyba ir sutrikusia fibrinolize, COVID-19 infekcijoje pasireiškia epiteliopatija, kuri prisideda prie mikrocirkuliacijos patofiziologinių pokyčių. SARSCoV-2 sukèlèjas jungiasi prie AKF-2 receptorių, randamų ne tik kvejpavimo taku epitelyje, bet ir kraujagyslių endotelyje, aktyvindamas renino-angiotenzino-aldosterono sistemą, trombocitų agregaciją ir skatindamas interleukinų (IL) IL-2, IL-6 ir IL-10, naviko nekrozès faktoriaus $\alpha$ (TNF- $\alpha$ ) hiperprodukciją. Viruso dauginimasis sukelia uždegiminę ląstelių infiltraciją, endotelio apoptozę ir mikrovaskulinius protrombotinius pokyčius. Virusams patekus ị endotelio ląsteles, prasideda mononuklearų ir polimorfonuklearų infiltracija, kuri sukelia endotelio apoptozę. Šie mechanizmai sukelia mikrocirkuliacijos sutrikimus, kurie prisideda prie tolesnès patologijos eigos [9].

Kita COVID-19 infekcijos savybė yra prokoaguliantų atsakas ūmioje fazèje, kai ūmios fazès reagentai tiesiogiai koreliuoja su padidejusia trombozès rizika. Reikšmingas uždegimas būdingas pacientams, sergantiems sunkia COVID-19 ligos forma, atsižvelgiant ị padidejusį TNF- $\alpha$, IL-1 ir IL-6, kiekį, padidèjusị CRB, eritrocitų nusédimo greitị 
ir fibrinogeną, tačiau pastebèta, kad šie sutrikimai labiau būdingi RITS gydomiems pacientams. TNF- $\alpha$ ir IL-1 yra pagrindiniai endogeninès krešejimo kaskados slopinimo mediatoriai. Sergant sunkia COVID-19 ligos forma, randamas didelis kiekis uždegimą skatinančių citokinų ir chemokinų kiekis, sukeliantis citokinų audrą, nuo kurios neatsiejama ir imunotrombozè [10].

Imunotrombozè - tai fiziologinis procesas, kurio metu su lokaliu patogenu kovoja nespecifinè imuninè sistema. Esant ūminei infekcinei būklei, tarp krešejimo ir ịgimtos imuninès sistemos vyksta kryžminis grižtamasis ryšys, kuris ląstelių lygiu sukuria trombą, vadinamą imunotrombu. Aktyvinti ịimto imuniteto komponentai (imuninès ląstelès ir komplemento baltymai), sąveikoje su trombocitais ir koaguliacijos veiksniais, sukelia imunotrombozę. SARS-CoV-2, jungdamasis prie AKF-2 receptorių, pažeidžia kraujagyslių endotelio ląsteles, taip pritraukia trombocitus ir neutrofilus i pažaidos vietas. Suaktyvinti neutrofilai išspaudžia savo branduolinị turinị ị ekstraląstelinę erdvę, kad sudarytų neutrofilų ekstraląstelinius spąstus (NET), kurie atrasti 2004 m., kaip svarbi imuninès sistemos dalis. NET yra struktūros, sudarytos iš neutrofilų ekstraląstelinès DNR, histonų ir kitų antimikrobinių baltymų. Vis daugiau ịrodymų, kad trombocitai ir neutrofilai sąveikauja reguliuodami NET formavimąsi, kuriu susidarymo padidejjimas susijęs su tromboziniu poveikiu. NET aktyvuoja trombocitus ir fibriną, sudarydami tvirtą imunotrombą. Tai imuninio atsako prieš patogeną dalis suformuodamas trombą infekcijos vietoje, organizmas bando virusą inhibuoti ir stabdyti jo plitimą kituose audiniuose. Vis dèlto dalis aktyvuotos ir krešejimą aktyvinančios imuninès sistemos trombogeninių komponentų išplinta kraujyje. Kilus diseminuotos vidukraujagyslinès koaguliacijos sindromui, kai visame organizme atsiranda dauginių trombų, sutrinka daugybès organų veikla $[11,12]$.

Antifosfolipidiniai antikūnai buvo nustatyti daugeliui pacientų, sergančių COVID-19 liga. Šie antikūnai paprastai laikomi nepatogeniniais ir atspindi tik B ląstelių aktyvaciją, tačiau negalima atmesti jų vaidmens, skatinant arterijų trombozinius reiškinius COVID-19 metu [13].

Hipoksija, nustatyta esant sunkiai COVID-19 formai, gali padidinti kraujo klampumą ir nuo hipoksijos sukelto transkripcijos faktoriaus priklausomą signalizacijos kelią. Hipoksija prisideda prie koagulopatijos, konvertuodama iprastą endotelio fenotipą (atsparų tromboziniam aktyvumui) i protrombozini fenotipą, padidindama ankstyvojo augimo atsako 1 geno ir hipoksija indukuojančio faktoriaus 1 transkripciją [14].

Pacientams arterinè trombozè dažniausiai pasireiškia ūmioje ligos fazèje, kuriems yra aktyvi COVID-19 liga ir nenormalūs uždegiminiai rodikliai. Endotelio pažeidimas iš- lieka ir tiems pacientams, kuriems pasveikus nuo COVID-19 ligos, normalizavosi uždegiminiai rodikliai. Tai fenomenas, aprašytas A. Bozzani ir kt. [15], kai arterijų trombozė pasireiške praejjus dviem savaitèms po COVID-19 ligos, greičiausiai dèl užsitęsusios endotelio disfunkcijos net ir praejjus ūmiai COVID-19 ligos fazei.

Maždaug 20-50 proc. COVID-19 liga sergančių pacientų kraujo tyrimuose stebimi pakitimai: padidejęs d-dimeru, fibrinogeno, laktatdehidrogenazès, feritino ir krešèjimo faktorių kiekis, igyti antifosfolipidiniai antikūnai, sumažejęs C ir S baltymu antitrombino kiekis, padidèjęs trombocitų ir neutrofilu aktyvumas bei limfopenija. Visi šie rodikliai gali padèti ịvertinti hiperkoaguliacijos laipsnị. 46-63 proc. COVID-19 liga sergančių pacientų, kuriems išsivysto ūminè galūnès išemija, randamas padidèjęs d-dimerų kiekis, o staigus d-dimeru padidejimas rodo ūminę trombozę [16]. Tai galima pastebèti ir mūsų klinikiniu atveju. Atvykus pacientei stebèta trombocitozè (PLT- 474*10e9/1), padidèję uždegiminiai rodikliai (CRB-159,8 mg/l, PCT-0,11 $\mu \mathrm{g} / \mathrm{ml}$ ), padidejusi feritino koncentracija $(582,90 \mu \mathrm{g} / \mathrm{l})$, padidèję d-dimerai ir fibrinogeno koncentracija (d-dimerai - 2,47 $\mu \mathrm{g} / \mathrm{ml}$, fibrinogenas - 7,32 $\mathrm{g} / \mathrm{l}$ ), o išsivysčius ūminei išemijai stebėtas staigus d-dimeru padidejjimas (d-dimerai $->4,0 \mu \mathrm{g} / \mathrm{ml}$ ). N. Tang ir kt. įrodè, kad pacientų, sergančių sunkia COVID-19 ligos forma su plaučių uždegimu, mirties rizika buvo didesnè, esant žymiai padidejusiems d-dimerų ir fibrinogeno kiekiams, nei pacientų, kurių šios koncentracijos buvo normalios. D-dimerų koncentracija ir jų didejjimas tiesiogiai koreliuoja su mirties rizika: D-dimerų koncentracijai viršijant $1 \mu \mathrm{g} / \mathrm{ml}$, rizika mirti padideja 18 kartų [17].

Ūminè galūnių išemija apibrèžiama kaip staigus kraujotakos sumažèjimas, keliantis grèsmę galūnès gyvybingumui. Galūnès audiniai patiria ūminę išemiją, kurios vyraujantys simptomai yra skausmas, odos pabalimas, šaltumas, parestezijos, arterijų pulsacijos nebuvimas. Ūminès galūnių išemijos klinikinis pasireiškimas pacientams, sergantiems COVID-19 liga, yra sunkiai nuspejjamas ir nebūtinai susijęs su ligos sunkumu ar viruso aktyvumu. Nustatyta, kad vyrai dažniau serga nei moterys ir pacientams dažnai randamos dauginès trombozès, kurios paprastai pasireiškia apatinèse galūnėse. Femoropoplitinis segmentas - dažniausia trombo vieta, kaip ir mūsų pristatytu atveju. Pacientai, kuriems pasireiškè tik kojų išemijos simptomai, dažniau išvenge amputacijos ar mirties nei pacientai, turèję plaučių ar kitų sisteminių simptomų. Pastebèta, jog praejjus 5-7 dienoms po KFN pablogèjimo, ūminè galūnès išemija pasireiškia dažniau [18].

Standartinis ūminès galūnių išemijos gydymas - revaskuliarizacija kartu su antitrombocitinemis ir antikoaguliacinėmis priemonèmis. Hiperuždegiminès būsenos, endotelito ir su tuo susijusio endotelio pažeidimo poveikis svarbus ne 
tik üminei, bet ir pakartotinei trombozei po chirurginès ar endovaskulinès intervencijos. Tai patvirtina dažnas nesèkmingų atvejų skaičius dèl nesėkmingos revaskuliarizacijos. Nepaisant antikoaguliacijos, retrombozès rizika yra didelè dèl viruso sukeliamo nuolatinio endotelio pažeidimo, o pacientams, kuriems atlikta trombektomija, retrombozès rizika dar didesnè dèl patiriamo endotelio pažeidimo intervencijos metu. Konservatyvusis gydymas pasižymi didesne mirštamumo rizika, negu intervencinis, nors amputacijos rizika yra panaši. Dèl tokių išvadų ūminès galūnès išemijos gydymo protokolas buvo koreguotas, įtraukiant gydymą intravenine trombolize, daugiausia demesio skiriant nenutrūkstamo intraveninio heparino vartojimui po revaskuliarizacijos. Nors pooperacinis intraveninio heparino vartojimas su sèkminga revaskuliarizacija nebuvo reikšmingai susijęs, tačiau nei vienam pacientui, gavusiam ị veną heparino, pakartotinè intervencija nebuvo reikalinga ir stebetas didesnis pacientu išgyvenamumas. Gydymas heparinu veiksmingas ne tik koagulopatijos gydymui. Jo uždegimo slopinamosios bei antivirusinès savybès pasirodè naudingos pacientams, sergantiems COVID-19 liga. Tarpinè heparino dozè, paskirta tarp profilaktinių ir terapinių dozių, gali sumažinti COVID-19 pacientų trombozès atvejus. Žinoma, kad heparinas slopina citokinų audros vystymąsi, kuris yra tipiškas COVID-19 viruso patogenetinis procesas. Jau ịrodyta, kad heparinas suriša ir sukelia konformacinį SARS baltymo receptorių surišimo domeno (S1 RBD) pokytį. Ši sąveika yra susijusi su heparino slopinimu SARS-CoV-2 ląstelių invazijai, priklausomai nuo dozès, o tai žymiai sumažina patogeno aktyvumą, kuris prisijungia prie heparino molekulių, užuot atakavęs organizmo ląsteles, slopindamas ląstelių įsiskverbimą [19,20].

Pacientams, kurių padidèjęs d-dimerų kiekis, naudinga antikoaguliacinè terapija, ypač MMMH. Pagal mokslines rekomendacijas, kaip išvengti COVID-19 sukeltos trombozès, jei nėra kontraindikacijų, stacionaro pacientams turètu būti skiriamas antikoaguliacinis tromboprofilaktinis gydymas mažos molekulinès masès ar nefrakcionuotu heparinu. Baigus aktyvų gydymą stacionare, toliau tęsti tromboprofilaktinị gydymą geriamaisiais antikoaguliantais ir K vitamino antagonistais dar bent 3 ménesius. Ambulatoriškai gydomiems COVID-19 pacientams venų ar arterijų trombozès profilaktikai antikoaguliantų ir antitrombocitinių vaistų naudoti nerekomenduojama [20].

\section{Išvados}

1. Šis klinikinis atvejis parodo, jog ūminè galūnès išemija dèl arterinès trombozès yra pavojinga COVID-19 ligos komplikacija, dažniausiai susijusi su nepalankiais intervencinio gydymo rezultatais, didele galūnès amputacijos rizika ir dideliu mirštamumu.
2. Po revaskuliarizacijos ilgalaikis sisteminio heparino vartojimas gali pagerinti chirurginio gydymo efektyvumą, galūnių išsaugojimą ir svarbiausia - sumažinti mirštamumą.

3. Siekiant sumažinti stacionare gydomų vidutine ir sunkia COVID-19 ligos forma sergančiu pacientų trombozines komplikacijas, nesant kontraindikacijų, rekomenduotinas antikoaguliacinis tromboprofilaktinis gydymas mažos molekulinès masès ar nefrakcionuotu heparinu.

\section{Literatūra}

1. Worldometer. COVID-19 Data. https:/www.worldometers.info/ coronavirus/

2. Behzad S, Aghaghazvini L, Radmard AR. Extrapulmonary manifestations of COVID-19: radiologic and clinical overview. Clin Imaging 2020;66:35-41.

https://doi.org/10.1016/j.clinimag.2020.05.013

3. Levi M, Thachil J, Iba T, Levy JH. Coagulation abnormalities and thrombosis in patients with COVID-19. Lancet Haematol 2020;7:438-440.

https://doi.org/10.1016/S2352-3026(20)30145-9

4. Klok F, Kruip M, van der Meer N, et al. Incidence of thrombotic complications in critically ill ICU patients with COVID-19. Thromb Res 2020;191:145-147.

https://doi.org/10.1016/j.thromres.2020.04.013

5. Abou-Ismail MY, Diamond A, Kapoor S, Arafah Y, Nayak L. The hypercoagulable state in COVID-19: incidence, pathophysiology, and management. Thromb Res 2020;194:101-115. https://doi.org/10.1016/j.thromres.2020.06.029

6. Etkin Y, Conway AM, Silpe J. Acute arterial thromboembolism in patients with COVID-19 in the new york city area. Ann Vasc Surg 2021;70:290-294.

https://doi.org/10.1016/j.avsg.2020.08.085

7. Lu R, Zhao X, Li J, Niu P, Yang B, Wu H, et al. Genomic characterisation and epidemiology of 2019 novel coronavirus: implications for virus origins and receptor binding. Lancet 2020;395:565-74.

https://doi.org/10.1016/S0140-6736(20)30251-8

8. Siddiqi HK, Mehra MR. COVID-19 illness in native and immunosuppressed states: A clinical-therapeutic staging proposal. J Heart Lung Transplant 2020;39(5):405-407.

https://doi.org/10.1016/j.healun.2020.03.012

9. Hoffmann M, Kleine-Weber H, Schroeder S, Krüger N, Herrler T, Erichsen S, et al. SARS-CoV-2 cell entry depends on ACE2 and TMPRSS2 and is blocked by a clinically proven protease inhibitor. Cell 2020;181:271-80.e278.

https://doi.org/10.1016/j.cell.2020.02.052

10. Levi M, Thachil J, Iba T, Levy JH. Coagulation abnormalities and thrombosis in patients with CO-VID-19. Lancet Haematol 2020;7:e438-e440.

https://doi.org/10.1016/S2352-3026(20)30145-9

11. Gaertner F, Massberg S. Blood coagulation in immunothrombo- 
sis - at the frontline of intravascular immunity. Semin Immunol 2016;28(6):561-569.

https://doi.org/10.1016/j.smim.2016.10.010

12. Engelmann B, Massberg S. Thrombosis as an intravascular effector of innate immunity. Nat Rev Immunol 2013;13:34-45. https://doi.org/10.1038/nri3345

13. Levi M, Iba T. COVID-19 coagulopathy: is it disseminated intravascular coagulation? Intern Emerg Med 2021;16(2):309312. https://doi.org/10.1007/s11739-020-02601-y

14. Tang N, Bai H, Chen X, Gong J, Li D, Sun Z. Anticoagulant treatment is associated with decreased mortality in severe coronavirus disease 2019 patients with coagulopathy. J Thromb Haemost 2020;18:1094-1099. https://doi.org/10.1111/jth.14817

15. Bozzani A, Arici V, Tavazzi G. Acute thrombosis of lower limbs arteries in the acute phase and after recovery from COVID19. Ann Surg 2021;273(4):e159-e160. https://doi.org/10.1097/SLA.0000000000004700

16. Piazza G, Morrow DA. Diagnosis, management, and pathophysiology of arterial and venous thrombosis in COVID-19. JAMA 2020;324(24):2548-2549. https://doi.org/10.1001/jama.2020.23422

17. Goldman IA, Ye K, Scheinfeld MH. Lower-extremity arterial thrombosis associated with COVID-19 is characterized by greater thrombus burden and increased rate of amputation and death. Radiology 2020;297:E263-E269.

https://doi.org/10.1148/radiol.2020202348

18. Bellosta R, Luzzani L, Natalini G, Pegorer MP, Attisani L, et al. Acute limb ischemia in patients with COVID-19 pneumonia J Vasc Surg 2020;72(6):1864-1872.

https://doi.org/10.1016/j.jvs.2020.04.483

19. Mycroft-West C J, Su D, Elli S.The 2019 coronavirus (SARS$\mathrm{CoV}-2$ ) surface protein (Spike) S1 receptor binding domain undergoes conformational change upon heparin bindingbioRxiv 2020. Accessed November 1, 2020. https://doi.org/10.1101/2020.02.29.971093

20. Moores LK, Tritschler T, Brosnahan S et al. Prevention, Diagnosis, and Treatment of VTE in Patients With Coronavirus Disease 2019. Chest 2020.

https://doi.org/10.1016/j.chest.2020.05.559

\section{A CLINICAL CASE OF COVID-19 ASSOCIATED ACUTE LIMB ISCHEMIA}

\section{R. Bružienè, G. Virketis, D. Brazys}

Keywords: arterial thrombosis, COVID-19, respiratory failure, complications, acute limb ischemia.

Summary

COVID-19 infection is characterized by a wide range of clinical manifestations. Venous thrombotic complications are the most common in COVID-19 disease, but arterial thrombotic complications are associated with a high risk of limb amputation and increased mortality. The article presents a clinical case of acute limb ischemia caused by COVID-19 disease with limb amputation and fatal outcome, and discusses the mechanisms of the development, diagnosis and treatment of this condition. The article reviews the experience of other authors in the treatment of patients with $\mathrm{CO}$ VID-19 infection, discusses the pathophysiological mechanisms in the body affected by COVID-19 infection, causing blood clotting, systemic inflammatory response, immune system changes, which caused thrombotic complications.

Conclusions. Long-term use of systemic heparin can improve the effectiveness of surgical treatment, preserve limbs, and reduce mortality. To reduce thrombotic complications, low-molecularweight or unfractionated heparin is recommended for inpatients with moderate to severe COVID-19.

Correspondence to: virketis@kul.1t

Gauta 2021-09-28 